Acat vet. scand. 1986, 27, 235-242.

From the National Veterinary Institute, Oslo, Norway.

\title{
FIMBRIAE IN ESCHERICHIA COLI ISOLATED FROM THE SMALL INTESTINE OF PIGLETS
}

\author{
By \\ Berit K. Djфnne and Eivind Liven
}

DJØNNE, BERIT K. and EIVIND LIVEN: Fimbriae in Escherichia coli isolated from the intestinal tract of piglets. Acta vet. scand. 1986, 27, 235-242. - Ninety E. coli strains. isolated from piglets which had died from neonatal diarrhea, were tested for the presence of $\mathrm{K88}$, K99, 987P and type 1 fimbriae. Two or more types of fimbriae were demonstrated in 14 of the strains, a single fimbrial type in 44 strains while in 32 strains no fimbriae were detected. Of the $14 \mathrm{E}$. coli strains with more than 1 type of fimbriae, 12, 10, 8 and 4 strains showed K88, $\mathrm{K} 99,987 \mathrm{P}$ and type 1 , respectively.

Twelve E. coli strains were isolated from piglets which had died in the neonatal period without showing signs of neonatal diarrhea at necropsy. One strain showed 987P and 3 strains showed type 1 fimbriae, while the remaining 8 strains were unfimbriated.

Sixteen fimbriated E. coli strains were subcultured in order to examine the stability of fimbrial expression in the strains. The K88 and the type 1 fimbriae were regularly expressed, while the K99 and 987P were inconsistently demonstrated.

pili; K-antigens; adhesins; neonatal diarrhea.

Neonatal diarrhea in piglets is often associated with strains of Escherichia coli (E.coli) which produce enterotoxins and harbour specialized fimbriae or pili, called adhesins. Such fimbriae enable the bacteria to adhere to the intestinal epithelium, an important step in the pathogenesis of neonatal diarrhea (Gastraa \& de Graaf 1982). Fimbrial adhesins found in strains of E. coli from piglets with diarrhea in Norway are K88 (F4), K99 (F5) and 987P (F6) (Lund et al. 1982, Ness 1983).

Most common in E. coli is the type 1 fimbria (F1), which is found in both pathogenic and non-pathogenic strains (Ottow 1975). Strains with type 1 fimbria can adhere to the intestinal epithelium of piglets (Isaacson et al. 1978). There has, however, been some discussion as to the significance of type 1 fimbriae in 
the pathogenesis of neonatal diarrhea (To et al. 1984, Jayappa et al. 1985).

It has generally been accepted that enteropathogenic E. coli strains can carry only 1 type of fimbria. However, in recent years, papers have been published reporting the demonstration of several types of fimbriae in single strains (Morris et al. 1982, Schneider \& To 1982). It has also been claimed that almost all enteropathogenic E. coli strains have the capacity to express 2 or more fimbriae (Brinton et al. 1983).

The purpose of the present investigation was to examine $\mathrm{E}$. coli strains, isolated from the intestines of piglets with lesions corresponding to those seen in neonatal diarrhea, for the simultaneous presence of different types of fimbriae. Some E. coli strains isolated from the intestine of piglets which had died from diseases other than neonatal diarrhea were included. Strains were also tested for their stability in expressing the different fimbriae and for their O-antigens.

\section{Piglets}

\section{MATERIAL AND METHODS}

Sixty-seven piglets necropsied at the National Veterinary Institute in Norway during 1984 and 1985 were used for the study. Gross lesions and bacteriological findings corresponding to those seen in neonatal diarrhea were observed in 55 piglets, while the remaining 12 had died for other reasons. The age of the animals varied between 1 and 14 days.

\section{E. coli strains}

Bacteriological examination of the contents of the small intestine was carried out according to standard cultural techniques using blood-agar and bromthymolblue-lactose agar. Plates were incubated at $37^{\circ} \mathrm{C}$ for approx. $20 \mathrm{~h}$. As regards the 55 piglets which had died from neonatal diarrhea, a single E. coli strain was isolated in 35 cases, while from 20 piglets $2-3$ strains were isolated. Altogether $90 \mathrm{E}$. coli strains were isolated from piglets which had died because of neonatal diarrhea. As regards the 12 piglets which had died for other reasons, only 1 E. coli strain was isolated from each piglet. The strains were identified according to standard cultural and biochemical methods. 


\section{Subcultivation procedure}

The E. coli strains were subcultured on semisynthetic medium (SSM) and trypticase soy broth (TSB), and incubated in a roller at $37^{\circ} \mathrm{C}$ for $72 \mathrm{~h}$. One loopful of the broth was transferred from SSM to a second SSM, and from TSB to a second TSB, and incubated, without shaking, at $37^{\circ} \mathrm{C}$ for 7 days. One loopful of the broth, from the pellicle if present, was streaked on Minca medium (Guinee et al. 1977) from the SSM, and on trypticase soy agar (TSA) from the TSB. The plates were incubated at $37^{\circ} \mathrm{C}$ for 24 $h$, and examined under a stereomicroscope $(6.4 \times)$ for the presence of different colonial forms. Each colonial form was subcultured on Minca medium or TSA, and incubated at $37^{\circ} \mathrm{C}$ for $24 \mathrm{~h}$.

\section{Demonstration of fimbriae and $\mathrm{O}$-antigens}

From Minca medium and TSA, the strains were tested for fimbriae by the slide-agglutination test, using 4 fimbriae-specific antisera (K88, K99, 987P and type 1).* The antisera were produced in rabbits, using purified fimbriae as antigens. Normal rabbit serum and physiological saline were used as negative controls, while the E. coli strains K12, K88, K12, K99, 103,09,987 $\mathrm{P}^{\star \star}$ and $\mathrm{B} 9$, type $1^{\star}$ were used as positive controls.

The E. coli strains were examined for $\mathrm{O}$-antigen $8,9,45,64$, $101,138,139,141,147,149$ and 157 by the tube agglutination test (Söderlind 1971), modified for microtitre plates.

\section{Stability of fimbrial expression}

To determine the stability of fimbrial expression, $8 \mathrm{E}$. coli strains with 1 fimbrial type (mono-fimbriated), and 8 strains with more than 1 type of fimbria (poly-fimbriated) after the first subcultivation, were further subcultivated twice employing the same subculture procedure. The $\mathrm{O}$-antigens of the strains were determined after each subcultivation.

\section{RESULTS}

Of the $90 \mathrm{E}$. coli strains isolated from the piglets with neonatal diarrhea and tested after a single subcultivation, 14 were

* Kindly supplied by Dr. H. G. Jayappa, Elkhorn Research Center, Shering Corporation, Elkhorn, Nebraska 68022, USA.

* * Kindly supplied by Dr. F. Ørskov, Statens Seruminstitut, 2300 Copenhagen S, Denmark. 
T a ble 1. Demonstration of fimbriae (K88, K99, 987P and type 1) and $\mathrm{O}$-antigens in $90 \mathrm{E}$. coli strains isolated from the intestines of 55 piglets which had died due to neonatal diarrhea.

\begin{tabular}{|c|c|c|c|c|c|c|c|c|c|}
\hline \multirow[b]{2}{*}{ Fimbriae } & \multirow{2}{*}{$\begin{array}{l}\text { No of } \\
\text { strains }\end{array}$} & \multicolumn{7}{|c|}{0 -antigen } & \multirow{2}{*}{$\begin{array}{l}\text { Not } \\
\text { tested }\end{array}$} \\
\hline & & 08 & 09 & 064 & 0141 & 0147 & 0149 & none & \\
\hline none & 32 & & 1 & & 1 & & 7 & 4 & 19 \\
\hline K88 & 33 & & 1 & & & & 32 & & \\
\hline К99 & 4 & & & 1 & & & 1 & 2 & \\
\hline type 1 & 7 & & & & 3 & & & 4 & \\
\hline K88+K99 & 6 & & & & & 1 & 5 & & \\
\hline $\mathrm{K} 88+987 \mathrm{P}$ & 2 & & & & & & 2 & & \\
\hline type $1+987 \mathrm{P}$ & 2 & 2 & & & & & & & \\
\hline $\mathrm{K} 88+\mathrm{K} 99+987 \mathrm{P}$ & 2 & & & & & & 2 & & \\
\hline $\begin{array}{c}\mathrm{K} 88+\mathrm{K} 99+987 \mathrm{P} \\
+ \text { type } 1\end{array}$ & 2 & 1 & & & & & & 1 & \\
\hline Total & 90 & 3 & 2 & 1 & 4 & 1 & 49 & 11 & 19 \\
\hline
\end{tabular}

found to be poly-fimbriated, 44 mono-fimbriated while in 32 strains no fimbriae were detected (Table 1 ).

The K88 antigen was possessed by 45 of the E. coli strains, 12 of which were poly-fimbriated. Fourty-one of the K88 positive strains belonged to O-group 149.

Of the E. coli strains from piglets with neonatal diarrhea, 14 strains revealed the K99 antigen. Ten of these strains were poly-fimbriated. The K99 positive strains had $\mathrm{O}$-antigens 8,64 , 147, 149 or were negative to the O-antisera used.

Eight of the $90 \mathrm{E}$. coli strains were found to possess the $987 \mathrm{P}$ antigen, always in association with other types of fimbriae. The strains with $987 \mathrm{P}$ had 08,0149 or were negative to the $\mathrm{O}$-antisera used.

Type 1 fimbriae were detected in 11 of the E. coli strains, 4 of which were poly-fimbriated. The strains with type 1 fimbriae had $\mathrm{O}$-antigens 8,141 or were negative to the $\mathrm{O}$-antisera used.

Eight of the 12 E. coli strains which were isolated from piglets which had died from causes other than neonatal diarrhea, were found to be non-fimbriated. Three strains had type 1 fimbriae and 1 strain had 987P. 08 antigen was found in 1 nonfimbriated and in 1 type 1-fimbriated E. coli strain. 0141 was detected in the other 2 strains with type 1 fimbriae. No O-antigens were demonstrated in the other E. coli strains from this group. 
T a b le 2. Stability of expression of fimbriae following repeated subcultivations of $16 \mathrm{E}$. coli strains isolated from the intestine of piglets which had died due to neonatal diarrhea.

\begin{tabular}{|c|c|c|c|}
\hline \multicolumn{3}{|c|}{ Types of fimbriae expressed in each subcultivation } & \multirow[b]{2}{*}{ O-antigen } \\
\hline First subcult. & Second subcult. & Third subcult. & \\
\hline type 1 & type 1 & K88+type 1 & 0141 \\
\hline type 1 & K88+type 1 & K88+type 1 & 0141 \\
\hline K88 & K88 & K88 & 0149 \\
\hline K88 & K88 & K88 & 0149 \\
\hline K99 & $\mathrm{K} 88+987 \mathrm{P}$ & K88 & 0149 \\
\hline K88 & K88 & K88 & 0149 \\
\hline K88 & K88 & K88 & 0149 \\
\hline K88 & K88 & K88 & 0149 \\
\hline $987 \mathrm{P}+$ type 1 & K88+type 1 & type 1 & 08 \\
\hline $987 \mathrm{P}+$ type 1 & type 1 & type 1 & 08 \\
\hline $\mathrm{K} 88+\mathrm{K} 99$ & $\mathrm{~K} 88+\mathrm{K} 99$ & $K 88+987 P$ & 0149 \\
\hline K88+K99 & K88+type 1 & none & 0149 \\
\hline $\mathrm{K} 88+\mathrm{K} 99$ & $\mathrm{~K} 88+\mathrm{K} 99+$ type 1 & K88+type 1 & 0149 \\
\hline $\mathrm{K} 88+\mathrm{K} 99$ & K88 & none & 0149 \\
\hline $\mathrm{K} 88+\mathrm{K} 99+987 \mathrm{P}$ & $\mathrm{K} 88+\mathrm{K} 99$ + type 1 & $\mathrm{~K} 88+987 \mathrm{P}+$ type 1 & 0149 \\
\hline $\begin{array}{c}\mathrm{K} 88+\mathrm{K} 99+987 \mathrm{P} \\
+ \text { type } 1\end{array}$ & $\begin{array}{c}\mathrm{K} 88+\mathrm{K} 99+987 \mathrm{P} \\
+ \text { type } 1\end{array}$ & none & 08 \\
\hline
\end{tabular}

The stability shown by 16 fimbriated E. coli strains in expressing the fimbriae is presented in Table 2. The results obtained after the first subcultivation were inconsistantly reproduced after the second and third subcultivation. The K88 and the type 1 fimbriae were more regularly recovered than the K99 and the 987P. The $\mathrm{O}$-antigen of the strains did not vary from one subcultivation to the next.

When more than $1 \mathrm{E}$. coli strain was isolated from the same piglet, not all the strains showed the same types of fimbriae. In 4 four of the 20 piglets, none of the isolated E. coli strains were fimbriated. In 11 piglets, all the fimbriated strains in the same piglet had the same type of fimbriae, although the proportion of the isolates which were fimbriated varied. In 5 piglets, E. coli strains with different fimbriae were found in the same individual. In some of these piglets, the E. coli strains were poly-fimbriated, while in others the strains isolated were mono-fimbriated, the fimbrial type varying in individual cases. 


\section{DISCUSSION}

In the present study, the frequencies of poly-, mono- and nonfimbriated E. coli strains isolated from piglets with lesions corresponding to neonatal diarrhea were found to be $16 \%, 49 \%$ and $36 \%$, respectively.

Brinton et al. (1983) found $82 \%$ poly-fimbriated E. coli strains and $16 \%$ with 1 fimbria from cases of neonatal diarrhea in swine in the United States. The results of the present investigation, in which similar methods and the same antisera were used (Jayappa et al. 1985), confirm their findings that poly-fimbriation is common. The frequency of poly-fimbriation found in the present study was, however, considerably lower than that reported by Brinton et al. In contrast to the latter study, the present investigation involved only a single subcultivation procedure.

In particular, the prevalence of $\mathrm{E}$. coli strains with type 1 fimbriae was low in the present investigation compared with the results reported by Brinton et al. (1983). Type 1 fimbriae were detected less often in strains from piglets which had died from neonatal diarrhea, than in strains from piglets who had suffered from other diseases. These findings might indicate that type 1 fimbriae are of limited importance for the enteropathogenicity of E. coli strains.

When more than 1 E. coli strain was isolated from each piglet, the strains sometimes expressed different fibriae and also different $\mathrm{O}$-antigens. These results, which are in accordance with the results reported by Djønne \& Liven (1983) and Francis $\&$ Wilson (1985), emphasize the importance of examining more than 1 colony from the primary plates. When the E. coli strains were further subcultivated, the fimbriae expressed could differ from one subcultivation to another. In contrast to K99 and 987P, changes in the expression of $\mathrm{K88}$ and type 1 fimbriae were rarely seen. Rhen et al. (1983) detected 4 different fimbriae in 1 uropathogenic E. coli strain, and they further demonstrated phase variation in fimbrial expression. The type 1 fimbria was also involved in the phase variation (Nowicki et al. 1984). A similar phase variation has not so far been demonstrated in enteropathogenic E. coli strains. The present study, however, indicates that the possibility of this phenomenon occurring in these strains should not be overlooked.

The variability in fimbrial expression observed in this study 
might not necessarily reflect the in vivo situation. The presented findings, however, provide supportive evidence for the existence of variation in fimbrial expression. If the fimbriae present in vivo are indeed different from those demonstrated by in vitro methods, this phenomenon could be explained by the growth conditions in the intestinal tract, and also by the possible effect of immunoglobulins from the vaccinated dams. Depending on the composition of the vaccine used, immunization might inhibit the expression of some fimbriae and stimulate the production of others in E. coli strains with identical genetic determinants.

The conclusion is drawn that the present study confirms the complexity of fimbrial adhesins in enteropathogenic E. coli strains. To elucidate this further, studies of genetic determinants controlling expression of fimbriae in enteropathogenic E. coli could be of interest. Such studies would provide information concerning the genetic potential, determining the ability of these strains to produce several types of fimbriae.

\section{ACKNOWLEDGEMENTS}

The excellent technical assistance of Tove Nilsen is highly appreciated.

\section{REFERENCES}

Brinton, C. C., P. Fusco, S. Wood, H. G. Jayappa, R. A. Goodnow \& J. G. Strayer: A complete vaccine for neonatal swine colibacillosis and the prevalence of Escherichia coli pili on swine isolates. Vet. Med. / Small Animal Clin. 1983, 00, 962-966.

Djønne, B. K. \& E. Liven: O-antigens, K-antigens and production of enterotoxin in Escherichia coli-strains isolated from litter mate piglets with neonatal diarrhea. Acta vet. scand. 1983, 24, 325327.

Francis, D. H. \& R. A. Wilson: Concurrent infection of pigs with enterotoxigenic Escherichia coli of different serogroups. J. clin. Microbiol. 1985, 22, 457-458.

Gaastra, W. \& F. K. de Graaf: Host-specific fimbrial adhesions of noninvasive enterotoxigenic Escherichia coli strains. Microbiol. Rev. 1982, 46, 129-161.

Guinee, P. A. M., J. Veldkamp \& W. H. Jansen: Improved Minca medium for the detection of K99 antigen in calf enterotoxigenic strains of Escherichia coli. Infect. Immun. 1977, 15, 676-678.

Isaacson, R. E., P. C. Fusco, C. C. Brinton \& H. W. Moon: In vitro adhesion of Escherichia coli to porcine small intestinal epithelial cells, pili as an adhesive factor. Infect. Immun. 1978, 21, $392-397$.

Jayappa, H. G., R. A. Goodnow \& S. J. Geary: Role of Escherichia coli type 1 pilus in colonization of porcine ileum and its protective 
nature as a vaccine antigen in controlling colibacillosis. Infect. Immun. 1985, 48, 350-354.

Lund, A., K. Fossum \& E. Liven: Serological, enterotoxin-producing and biochemical properties of Escherichia coli isolated from piglets with neonatal diarrhea in Norway. Acta vet. scand. 1982, $23,79-87$.

Morris, J. A., C. Thorns, A. C. Scott, W.J.Sojka \& G. A. Wells: Adhesion in vitro and in vivo associated with an adhesive antigen (F41) produced by a K99 mutant of the reference strain Escherichia coli B41. Infect. Immun. 1982, 36, 1146-1153.

Ness, E.: The detection of the 987P antigen in Escherichia coli isolated from piglets with diarrhoea. Acta vet. scand. 1983, 24, 521-523.

Nowicki, B., M. Rhen. V. Väisanen-Rhen, A. Pere \& T. K. Korhonen: Immunofluorescence study of fimbrial phase variation in Escherichia coli KS71. J. Bacteriol. 1984, 160, 691-695.

Ottow, J. C. G.: Ecology, physiology and genetics of fimbriae and pili. Ann. Rev. Microbiol. 1975, 29, 79-108.

Rhen, M., P. H. Mäkela \& T. K. Korhonen: P-fimbriae of Escherichia coli are subject to phase variation. FEMS Microbiol. Lett. 1983, 19, 267-271.

Schneider, R. A.\& S. C.M. To: Enterotoxigenic Escherichia coli strains that express $\mathrm{K} 88$ and $987 \mathrm{P}$ pilus antigens. Infect. Immun. 1982, $36,417-418$.

Söderlind, O.: Studies on Escherichia coli in pigs. II. Serological investigations. Zbl. Vet. Med. B. 1971, 18, 569-590.

To, S. C. M., H. W. Moon \& P. L. Runnels: Type 1 pili (F1) of porcine enterotoxigenic Escherichia coli: Vaccine trial and tests for production in the small intestine during disease. Infect. Immun. $1984,43,1-5$.

\section{SAMMENDRAG}

Fimbrier hos Escherichia coli isolert fra tynntarmen hos spedgris.

Nitti E. coli stammer isolert fra 55 spedgriser d $\phi$ de av neonatal diare, er unders $\varnothing \mathrm{kt}$ med hensyn på fimbrier (K88, K99, 987P og type 1). Fjorten av stammene hadde mer enn 1 fimbrie, 44 stammer hadde en fimbrie hver og 32 stammer ble funnet å være uten fimbrier. Av de 14 E. coli stammene med mer enn 1 fimbrie, hadde, 12, 10, 8, og 4 stammer henholdsvis K88, K99, 987P og type 1.

Tolv E. coli stammer isolert fra spedgriser døde av andre årsaker enn neonatal diare ble inkludert. En av disse stammene hadde 987P, 3 hadde type 1 mens de resterende 8 stammene var uten fimbrier.

Seksten E. coli stammer med fimbrier ble subkultivert for å undersøke reproduserbarheten i påvisningen av fimbriene. K88 og type 1 fimbriene ble ofte gjenfunnet, mens K99 og 987P ikke kunne reproduseres i samme grad.

\section{(Received February 7, 1986).}

Reprints may be requested from: Berit $K$. Djønne, the National Veterinary Institute, P.O. Box 8156 Dep, N-0033 Oslo 1, Norway. 